\title{
THE EFFECT OF SOCIAL MEDIA ORIENTATION ON MARKETING PERFORMANCE THROUGH VILCHIC BRAND IMAGE
}

\author{
Lilis Suryani ${ }^{1)}$, Syahmardi Yacob ${ }^{2)}$, Musnaini ${ }^{3)}$ \\ 1,2,3) Department of Management, Faculty of Economic and Business Jambi University, Jambi, Indonesia \\ Corresponding author: lilis.suryani192001@gmail.com
}

\begin{abstract}
This study aims to determine the influence of Social Media Orientation, Marketing Performance, and Brand Image. This research uses a quantitative descriptive method with Partial Least Square (PLS) Professional analysis tool. The subjects of this research are consumers who use vilchic masks in Jambi and outside the city of Jambi. The sampling technique used is purposive sampling. The number of samples used in this study amounted to 125. The results of this study indicate that social media orientation does not affect the marketing performance of vilchic companies. Social media has a significant impact on brand image, and brand image can affect the marketing performance of vilchic companies. The brand image variable in this study can influence or mediate between the marketing performance variables and the social media orientation, meaning that this research is full mediation. The findings of this study contribute that Brand Image is an essential factor in seeing the sales performance of vilchic companies.
\end{abstract}

Keywords: Social Media Orientation, Brand Image, Marketing Performance

\section{Introduction}

The development of increasingly sophisticated information and communication technology, both in developing and developed countries, has indirectly changed human lifestyles in everyday life. With lifestyle changes, people are more likely to use the internet to get information and needs quickly.

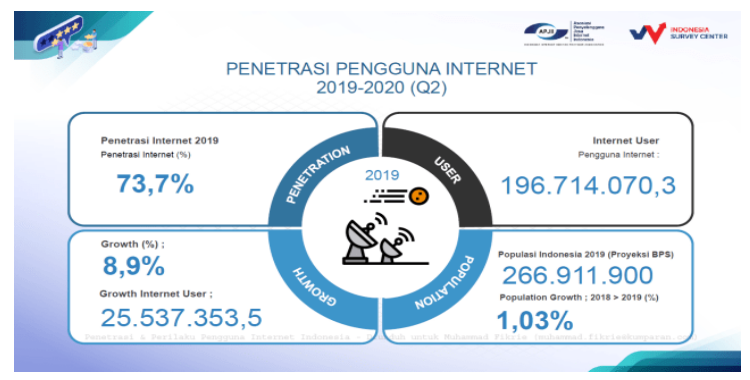

Figures 1. Penetration of Internet Users in Indonesia

Based on data from the Indonesian Internet Service Providers Association (APJII), internet users in Indonesia will continue to increase. This can be seen where the increase in internet users by 8.9 percent or equivalent to 25.5 million percent from the same period last year.

With the increase in internet use in Indonesia, people are more likely to use social media to get something in various aspects of life. This social media device is a common thing that is always in contact with our activities, especially for internet users (Ekasari, 2014). In Indonesia, social media users are growing very significantly. In addition, the use of social media platforms also has a significant impact on business people in maintaining the viability of a business. Social media is a new phenomenon that has changed how the business environment operates. . With the available social media platforms, they can effectively strengthen other communication activities (Kotler \& Keller, 2016). The benefits of social media include facilitating strategies, reducing costs, gathering information, increasing databases, and delivering services (Habibi et al., 2015).

Promotion strategies through social media will increase the marketing performance of business people. Marketing performance is a company strategy to measure the factors caused by the company's strategy, and the strategy is always directed or focused on sales volume and growth rate (Almaidah, 2019). Marketing performance is a measure of achievement obtained optimally in implementing the right

Strategy to manage its business properly. For this reason, marketing strategies must be designed to realize continuous competitive advantage, affecting marketing performance (Hartanty \& Ratnawati, 2013).

To help measure the performance of a marketing course, there are many influencing factors, one of which is the brand image. A good brand image can give consumers the perspective that the product will provide a sense of security when consumers buy it. (P. Kotler, 2012). The better the brand image attached to the product, the more interested consumers are in purchasing the product. 
Vilchis is a local organic mask product based in Jambi City. Vilchis is a new mask brand that is still 1.6 years old. Vilchis has succeeded in penetrating the national market as one of Indonesia's pioneers of local masks. The Indonesian government, especially the City of Jambi, is very supportive of local brands; this is evidenced by the award given by Bank Indonesia Jambi Province to the vilchic brand.

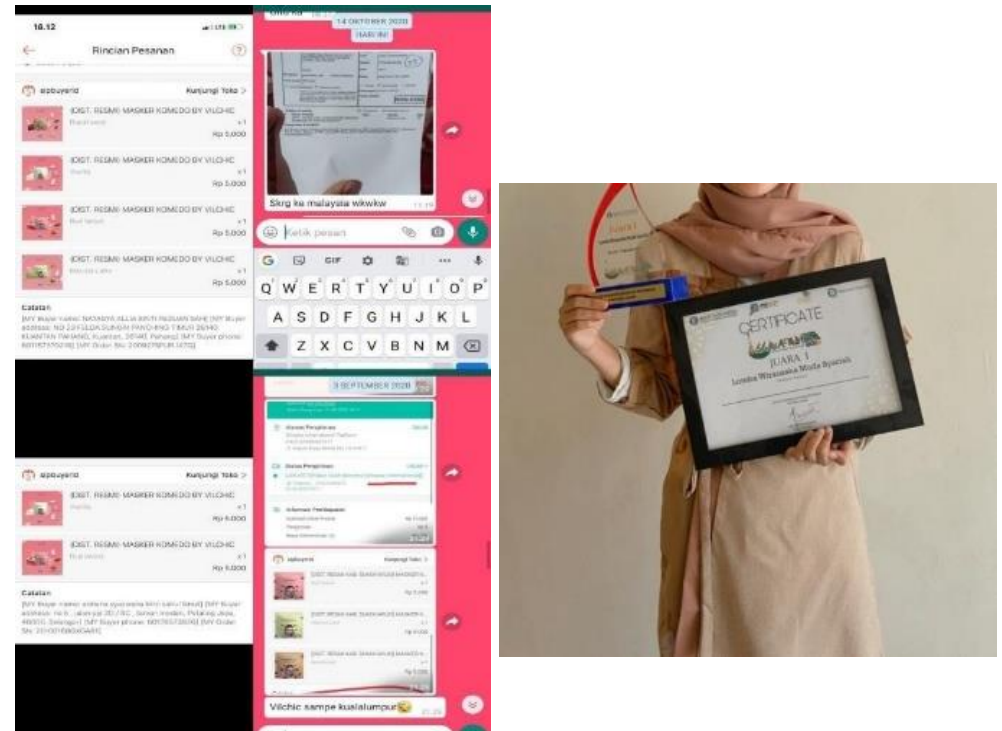

Figures 2. Vilchis Deals and Rewards

Various kinds of achievements have been obtained by the Vilchic brand, one of which is "Product appreciation and exhibition by the Deputy Chancellor III of Jambi University and being the 1st place winner in a competition held by Bank Indonesia Jambi Province in 2021". Not only the achievements obtained by Vilchis, but Vilchis also has several similar competitors such as organic masks, one of which is from the mypuepue brand and the daisy mask brand. Currently, the marketing strategy and delivery of advertisements from the vilchic brand uses platforms through social media, especially the Instagram and TikTok platforms, to promote the vilchic brand. Previously, Vilchis only employed the door-to-door system or those who wanted to become the official distributor of the vilchic mask brand. With a relatively new brand age, Vilchic has managed to reach as many as 50 distributors and 120 authorized resellers in the city of Jambi and outside the City of Jambi.

As well as the research gap that was found, research conducted by research (Ratana, 2018) found that social media as a promotional media was included in the very good classification as one of the supporting factors for marketing performance, on the contrary, in this study, it was stated that social media orientation did not have a significant influence. On marketing performance. Marketing performance is an indicator of work success or actual work performance achieved by a person or organization to carry out their duties well. Marketing performance is always seen as carrying out a specific strategic role. For a salesperson, performance is produced due to the aggressiveness of salespeople approaching and serving their customers well (Augusty \& Asatuan, 2004). Thus the author will examine the "Effect of social media orientation on marketing performance through brand image."

\section{Literature Review \\ Social Media Orientation}

In the view of Kotler \& Keller (2016), social media is a means for consumers to share text, image, audio, and video information with each other and with companies, and vice versa. The research of

Dutot, V., \& Bergeron (2016) argues that social media orientation is a set of principles and goals that direct and influence company activities in the social media field for better performance. Social media orientation refers to a company's strategic orientation towards social media. (Imran \& Jian, 2018). Khatib (2016) mentions that social media orientation is divided into four dimensions, namely:

1. There is exciting and entertaining content

The existence of exciting and entertaining content is an advertisement or content that can attract the attention of followers/followers of social media platforms

2. There is an interaction between consumers and sellers

The easy interaction between consumers and sellers is one of the keys to attracting followers' attention when they see the public's response.

3. Ease of informing the public

The ease of social media platforms that can be accessed by all groups will make it easier for consumers to share information, content, posts with each other. 
4. The level of trust in social media

The story of faith in social media can make followers more confident in the content or content provided by social media platforms.

\section{Brand Image}

A brand is a name, term, sign, symbol, or combination of these, intended to identify the goods or services of one seller or group of sellers and differentiate the products or services of competitors.

(Kotler, 2012). Kotler (2004) also states that brand image is perception and beliefs held by consumers, as reflected in the associations held in consumer memory, which means the brand image is perceptions and opinions held by consumers as reflected in associations stored in consumer memory. . Brand image is a relatively consistent perception in the long term ( enduring perception ).

Meanwhile, research by Aaeker, David, A, and Alexander (2009) states that brand image has three indicators:

1. Image Maker (Corporate Image) is a set of associations perceived by consumers to companies that make goods or services. Including popularity, credibility, corporate network, and the users themselves.

2. Consumer Product Image (Product Image) is a set of associations consumers perceive towards a product or service. Includes product attributes, benefits for consumers, and warranties.

3. User Image is a set of associations consumers feel towards users who use a product or service. Including the user himself, as well as his social status.

\section{Marketing Performance}

Marketing performance measures the success that a company can achieve in marketing its products in the market (Mulyani \& Mudiantono, 2015). Dewi's research (2016) explains that sales growth will depend on the number of customers whose average consumption level is known to be fixed,

A study conducted by Ferdinand (2003) stated that good marketing performance is expressed in three main quantities, namely:

1. Selling value is indicated by the value of money or units of product sold.

2. Sales growth as indicated by an increase in sales of the same product compared to a specific time unit.

3. Market share is indicated by the product's contribution in controlling the product market compared to competitors, which ultimately leads to company profits.

\section{Research Methods \\ Research design}

The research design used in this research is descriptive, and the illustrative purpose is to describe the effect of social media orientation on marketing performance through brand image. In this study, researchers distributed online questionnaires via a google form.

\section{Sample}

The population in this study is unknown. Therefore, for the number of samples obtained using the Malhotra formula in 2007. And the samples obtained in this study were 125 samples. The sampling technique used was purposive sampling, namely determining the sample with specific considerations (Sugiyono, 2017). The criteria for the sample selected in this study were: Consumers who had used a vilchic mask, either 1 time to more than 3 times, aged 15-35 years both inside Jambi City and outside Jambi City.

\section{Data analysis}

Data analysis technique used is quantitative data analysis techniques, the analysis used to examine the relationship or orientation Influence of Social Media , on the Performance Marketing with Brand Image . The instrument used in this study was a questionnaire with a Likert scale format. The Likert scale is used to measure attitudes, opinions, and perceptions of a person or group of social phenomena, which are scaled with 5 points. Alternative answers begin with a score of 1 , which means strongly disagree, to 5, which means strongly agree. Data were processed using Partial Least Square (PLS), which is a "powerful analytical method because it can be applied to all data scales, does not require many assumptions, and the sample size should not be significant. (Wiyono, 2011) PLS is a powerful analytical method because it can be applied to all data scales, does not require many assumptions, and the sample size does not have to be significant. Besides being used for theory confirmation, PLS can also be used to build relationships for which there is no theoretical basis or to test propositions.

\section{Result and Discussion}

The results table for inner weights from the results of running bootstrapping is used to determine the direct effect between the variables of each hypothesis. The trick is to see the value of the path coefficient of each hypothesis and the value of t-statistics. A good coefficient value must exceed $>0.5$. This coefficient is sourced from the original sample estimate column. The $\mathrm{t}$ - stat values are sourced from the $\mathrm{t}$-stat column in the results 
for the inner weights table. The t- statistic value above the value of 1.96 shows a significant direct effect of each hypothesis.

Table 1. Hypothesis Test

\begin{tabular}{|c|c|c|c|c|c|}
\hline Hypothesis & $\begin{array}{c}\text { Original Sample } \\
\text { estimate }\end{array}$ & $\begin{array}{c}\text { Mean of } \\
\text { subsamples }\end{array}$ & $\begin{array}{l}\text { Standard } \\
\text { Deviation }\end{array}$ & T-Statistic & P-Value \\
\hline $\begin{array}{l}\text { Social Media } \\
\text { Orientation } \longrightarrow \\
\text { Marketing } \\
\text { Performance }\end{array}$ & -0.095 & -0.091 & 0.133 & 0.714 & 0.476 \\
\hline $\begin{array}{l}\text { Social Media } \\
\text { Orientation } \longrightarrow \\
\text { Brand Image }\end{array}$ & 0.874 & 0.869 & 0.041 & 21.521 & 000 \\
\hline $\begin{array}{l}\text { Brand } \\
\text { Image } \longrightarrow \\
\text { Marketing } \\
\text { Performance }\end{array}$ & 0.874 & 0.861 & 0.127 & 6.858 & 000 \\
\hline $\begin{array}{l}\text { Social Media } \\
\text { Orientation } \longrightarrow \\
\text { Marketing } \\
\text { Performance } \\
\text { through brand } \\
\text { image }\end{array}$ & 0.765 & 0.750 & 0.126 & 6.087 & 0.00 \\
\hline
\end{tabular}

\section{Direct Influence}

1. Based on table 1 above, it can be seen that the original sample estimate value for social media orientation is -0.095 with a t-statistic value of 0.714 . The initial sample estimate value is more significant than 1.96 , which means it identifies that social media orientation has a negative and insignificant effect on marketing performance.

2. The test results show that social media orientation has an original sample estimate value of 0.874 with a tstatistic value of $21,521>1.96$, which means that social media orientation has a direct, positive, and significant effect $21.521 \%$ on brand image.

3. Based on the test results, the brand image obtained an original sample estimate of 0.874 with a t-statistic value of $7.151>1.962$, which means that the brand image variable has a direct, positive, and significant effect of $71.51 \%$ on marketing performance.

\section{Indirect Influence}

Based on the test results, $\mathrm{H} 4$ obtained the original sample estimate value of 0.765 with a t-statistic value of $6.087>1.962$, which means that the social media orientation variable towards marketing performance through brand image can be influenced by $60.8 \%$ and is significant.

\section{Discussion}

\section{The Effect of Social Media Orientation on Marketing Performance}

Thus, social media orientation (X) on marketing performance (Y) has no significant effect. By taking into account the original sample estimate, which is -0.095 . With a negative initial sample estimate value, it can be concluded that the social media orientation cannot affect the object's marketing performance.

This study is not in line with research, which means it does not follow previous research (Anggraeni \& Sanaji, 2021). This study indicates that social media has a positive and significant effect on innovation capability and branding capability and helps SMEs improve their marketing performance, which states that social media orientation positively impacts marketing performance.

\section{The Influence of Social Media Orientation on Brand Image}

Thus it can be concluded that social media orientation $(\mathrm{X})$ has a positive and significant influence on Brand Image $(Z)$. By paying attention to the positive and significant value of the original sample estimate, it can be concluded that the more often the company posts something on social media about the brand, the more consumers become aware of the existence of the product or service it has (Shen \& Bissell, 2013). By using social media, the company can also monitor consumer interest through the insights contained in social media. The results in this study follow previous research studies (Fahmi et al., 2019). Where the results of the study state that social media has a positive or significant effect on brand image. In addition to previous research from 
Fahmi, research from (Suwarsih et al., 2021) also states that social media orientation also positively affects brand image.

\section{The Effect of Brand Image on Marketing Performance}

It can be concluded that brand image $(\mathrm{Z})$ influences the company's marketing performance (Y). It is proven from the results of brand image testing that the original sample estimate value is 0.874 with a t-statistic value of 6.858. It can be concluded that the previous research studied by (Mani 2018) is appropriate and in line with this research. Where the results of the study stated that brand image had a significant positive effect on marketing performance. Brand image is considered the primary key in achieving marketing performance. (Khatib, 2016) states that the better the brand image attached to consumers, the more consumers are interested and know about the product.

\section{Effect of Social Media Orientation on Marketing Performance Mediated by Brand Image.}

Based on the analysis and test results through smart pls professional, social media orientation $(\mathrm{X})$ does not significantly affect marketing performance (Y). However, when mediated through brand image $(\mathrm{Z})$, the original sample value is 0.765 and the t-statistic 6.087, which indirectly has a positive and significant influence. Based on the results of the comparison of direct and indirect effects tests, it can be seen that the test results have changed and are substantial. This is following the role of mediation according to (Baron \& Kenny, 1986) that complete mediation ( Fully mediated ) will occur if the effect of the mediating variable on the dependent variable is significant while the independent variable on the mediator is not significant. In this study, it can be concluded that brand image is strong enough to mediate the influence of social media orientation to influence the marketing performance of the vilchic brand.

From the results of the primary data of this study, it can be concluded that the fourth hypothesis is in line with previous research. Research (Johar., et al., 2021) " states that brand image has a significant influence in mediating the relationship between the effects of social media use on marketing performance. This means that the use of social media influences marketing performance through the ability of brand image. In addition, in their research (Anggraeni \& Sanaji, 2021), they state that innovation and branding ability successfully mediate the effect of the relationship between the use of social media on marketing performance.

\section{Conclusion}

1. Social media orientation is not one of the determining factors in improving the marketing performance of vilchic products.

2. Social media orientation is a very decisive factor in improving brand image.

3. Brand image is a determining factor in increasing sales performance by vilchic products.

4. Brand image is one of the indirect factors (indirect effect ) that can contribute or be able to mediate the influence of social media orientation on the sales performance of vilchic products.

\section{Suggestion}

Practitioners/business people are expected to continue to use natural ingredients or choose ingredients that are safe in skincare ingredients. So it is safe for long-term use. The government/public is expected to continue assisting and supporting local products, especially the Jambi provincial government. And academics are expected to contribute to marketing strategies by looking at social media orientation, brand image, and marketing performance.

\section{References}

Aaeker, David, A and Alexander, LB (2009). Brand, Brand Equity and Advertising: Advertising Role In Building Strong. Lawrence Erlbaum Associates, Inc. https://psycnet.apa.org/record/1993-97857-000

Almaidah, S. (2019). Analysis of the Effect of Market Orientation on Competitive Advantage and Its Impact on Improving SME Marketing Performance. Unisri Research Fair, 3 (1), 448-455.

Anggraeni, M., \& Sanaji, S. (2021). The Influence of the Use of Social Media on Marketing Performance during the Covid-19 Pandemic by Mediation of Innovation Ability and Branding Ability (Study on MSME Actors Using Social Media). Journal of Management Science , 9 (2), 752. https://doi.org/10.26740/jim.v9n2.p752-767

Baron, RM, \& Kenny, DA (1986). The Moderator-Mediator Variable Distinction in Social Psychological Research. Conceptual, Strategic, and Statistical Considerations. Journal of Personality and Social Psychology, 51 (6), 1173-1182. https://doi.org/10.1037/0022-3514.51.6.1173

Dewi, ST (2016). Analysis of the Effect of Market Orientation and Product Innovation on Competitive Advantage to Improve Marketing Performance (Study on the Batik Industry in Pekalongan City and Regency). Economics And Business, 80. https://core.ac.uk/download/pdf/11715776.pdf

Dutot, V., \& Bergeron, F. (2016). From Strategic Orientation to social media orientation improves the performance of SMEs on social media. Journal of Small Business And Business Development, 23 (4). 
Ekasari, N. (2014). The effect of social media-based promotions on purchasing decisions for vehicle financing services at PT. BFI Finance Jambi. Jambi University Research Journal: Humanities Series, 16(2), 43450. Journal of Chemical Information and Modeling, 16, 81-102.

Fahmi, M., Arif, M., Farisi, S., \& Purnama, NI (2019). The Role of Brand Image in Mediating the Effect of Social Media Marketing on Repeat Purchase at Fast-Food Restaurant in Medan City. Ocean Journal of Economics And Business, 11 (1), 53-68. https://doi.org/10.33059/jseb.v11i1.1722

Ferdinand, A. (2003). Marketing Management: A Strategic Approach. Research Paper Series, 1 (5), 1-55. Habibi, H., Anne, C., John, M., \& Brendan, M. (2015). This is the authors' final peered review ( post-print )

the version of the item published as: Available from Deakin Research Online: E-Marketing orientation and social media implementation in B2B marketing. European Business Review, 27 (6), 1-18.

Hartanty, IT, \& Ratnawati, A. (2013). Improved marketing performance through optimization of competitive advantage. Journal of Economics And Business, 14 (2), 72-89.

Imran, M., \& Jian, Z. (2018). Social Media Orientation and SME Export Performance: A Conceptual Framework. International Journal of Management, Accounting \& Economics, 5 (6), 473-481. http://proxy.lib.sfu.ca/login?url=https://search.ebscohost.com/login.aspx?direct=true \&db=bth\&AN=1309 $58424 \&$ site=ehost-live

Khatib, F. (2016). The Impact of Social Media Characteristics on Purchase Decision Empirical Study of Saudi Customers in Aseer Region. International Journal of Business and Social Science, 7 (4), 41-50.

Kotler \& Keller. (2016). Kotler \& Keller - Marketing Management. In Boletin cultural e informativo - Consejo General de Colegios Medicos de Espaa (Vol. 22).

Kotler, M., \& Kotler, P. (2004). KOTLER. Signs , 1-8.

Kotler, P. (2012). Kotler P. Marketing management/Philip Kotler, Kevin Lane Keller. Pearson Educ Int. 2012. Pearson Education International.

Mulyani, IT, \& Mudiantono. (2015). Efforts to Improve Marketing Performance Through Market Orientation and Entrepreneurship Orientation With Innovation As Intervening Variable. Diponegoro Journal of Management, 4 (3), 1-12.

Ratana, M. (2018). Effect of Social Media Marketing on Brand Equity. Journal of Communication and Media Studies, 22 (1), 13. https://doi.org/10.31445/jskm.2018.220102

Shen, B., \& Bissell, K. (2013). Social Media, Social Me: A Content Analysis of Beauty Companies' Use of Facebook in Marketing and Branding. Journal of Promotion Management, 19 (5), 629- 651. https://doi.org/10.1080/10496491.2013.829160

Suwarsih, N., Gunawan, T., Parahyangan, UK, \& Parahyangan, UK (2021). The Effect of Social Media on Brand Image and Purchase Intention. Journal of Od Economics, Business, and Accounting, 4 (2), $712-730$.

Wiyono, G. (2011). Designing Business Research with SPSS 17.0 \& Smart PLS 2.0 Analysis Tools. YKPM STIM Printing. 